\title{
FAKTOR-FAKTOR YANG BERHUBUNGAN DENGAN KEJADIAN ISPA PADA ORANG DEWASA DI DESA BESUK KECAMATAN BANTARAN KABUPATEN PROBOLINGGO
}

\author{
FACTORS RELATED TO ACUTE RESPIRATORY INFECTIONS (ARI)INCIDENCE \\ IN ADULTS AT THE VILLAGE OF BESUK-BANTARAN - PROBOLINGGO
}

\author{
Anindea EIma Putri \\ Fakultas Kesehatan Masyarakat Universitas Airlangga, anindeaep@gmail.com
}

\begin{abstract}
Acute Respiratory Infections (ARI) is an upper or lower respiratory tract disease which it severity depends on the pathogen, environmental factors and host factors. At Besuk Village, most of villagers are suffered from ARI. Based on data from Bantaran Community Health Center, reports from 2014 through 2015 showing the number of people at Besuk village suffered from ISPA is 336 people. ISPA is ranked first for the type of disease which is most suffered by the villagers at Besuk Village rater than infectious diseases and other non-infectious diseases. The aim of this study was to determine factors associated with the incidence of ARI at Besuk Village. This research was using analytic survey with cross sectional study. The study population was villagers of Besuk Village amounting to 1.344 people. The sampling method was using the principle of simple random sampling. So it can be obtain the final number of respondents were 60 people as the study sample. The independent variables were the presence of dust in space, frequency of sweeping the house, use a mask when out of the house, residential density bed, spacious kitchen ventilation, and the type of the house's floor, while the dependent variable was the incidence of ARI in adults. Data were statistically tested using Chi-square with significance level $\alpha<0.1$. The results showed that there were three factors related to ISPA, namely the existence of space dust $(p=0.006)$, frequency sweep home $(p=0.083)$, and the use of masks when came out from home $(p=0.099)$. This shows that the residents of the village of tomorrow is not maximized in keeping the house clean and keep away from dangerous pollutants in the environment. Therefore, tomorrow Villagers advised to always keep the environment and the health of himself with a clean and healthy living behavior, and it is advisable to wear a mask when traveling outside the home due to the environmental conditions in the dusty village of tomorrow.
\end{abstract}

Keyword: acute respiratory infections, dust chamber, use of masks, frequency sweep 


\section{ABSTRAK}

ISPA merupakan jenis penyakit yang paling banyak diderita oleh warga Desa Besuk. Berdasarkan data laporan dari Puskesmas Bantaran mulai tahun 2014 sampai tahun 2015, jumlah penderita ISPA di Desa Besuk sebanyak 336 orang. ISPA menduduki peringkat pertama jenis penyakit yang paling banyak diderita oleh penduduk Desa Besuk dibandingkan penyakit infeksi maupun penyakit non infeksi lainnya. Penelitian ini bertujuan untuk mengetahui faktor apa saja yang berhubungan dengan kejadian ISPA di Desa Besuk. Penelitian ini menggunakan metode survei analitik dengan pendekatan cross sectional study. Populasi penelitian adalah warga Desa Besuk yang berada dalam rentang usia 20-44 tahun yang berjumlah 1.344 orang. Metode pengambilan sampel menggunakan prinsip simple random sampling sehingga didapatkan jumlah akhir responden sebanyak 60 orang sebagai sampel penelitian. Variabel independen meliputi keberadaan debu dalam ruang, frekuensi menyapu rumah, penggunaan masker saat keluar rumah, kepadatan hunian tempat tidur, luas ventilasi dapur, dan jenis lantai rumah, sedangkan variabel dependen adalah kejadian ISPA pada orang dewasa. Data penelitian diuji dengan uji statistik Chi-square dengan tingkat kemaknaan $\alpha<0,1$. Hasil penelitian menunjukkan bahwa terdapat tiga faktor yang berhubungan dengan ISPA yaitu keberadaan debu ruang $(\mathrm{p}=0,006)$, frekuensi menyapu rumah $(\mathrm{p}=0,083)$, dan penggunaan masker saat keluar rumah $(p=0,099)$. Hal ini menunjukkan bahwa warga Desa Besuk belum maksimal dalam menjaga kebersihan rumah dan menjaga diri dari polutan berbahaya di lingkungan. Oleh karena itu, Warga Desa Besuk disarankan untuk selalu menjaga kebersihan lingkungan dan kesehatan dirinya dengan berperilaku hidup bersih dan sehat, serta disarankan untuk memakai masker saat bepergian ke luar rumah dikarenakan kondisi lingkungan di Desa Besuk yang berdebu.

\section{Kata kunci: ISPA, debu ruang, penggunaan masker, frekuensi menyapu}

\section{PENDAHULUAN}

Infeksi Saluran Pernapasan Akut (ISPA) merupakan penyakit saluran pernapasan bagian atas atau bawah yang dapat menimbulkan berbagai spektrum penyakit dari penyakit tanpa gejala atau infeksi ringan sampai penyakit yang parah dan mematikan, tergantung pada patogen penyebabnya, faktor lingkungan, dan faktor pejamu. Penyakit ISPA biasanya menular (WHO, 2007).

Penyakit pada saluran pernapasan akan mempengaruhi saluran udara dalam sistem pernafasan, termasuk saluran hidung, bronkus, dan paru-paru. Penyakit ini dapat berupa infeksi akut, seperti pneumonia dan bronkitis, maupun kondisi kronis seperti asma dan penyakit paru obstruktif kronik (WHO, 2016).

ISPA disebabkan oleh lebih dari 300 jenis bakteri, virus, dan riketsia. Bakteri yang dapat menyebabkan ISPA antara lain dari genus Streptokokus, Stafilokokus, Hemofilus, Bordetela, Corinebakterium, dan Pneumokokus, sedangkan virus yang dapat menyebabkan ISPA antara lain dari golongan Pikornavirus, Herpesvirus, Miksovirus, Adenovirus, dan Mikoplasma (Halim, 2012).

Faktor yang mempengaruhi timbulnya kejadian ISPA antara lain adalah faktor demografi yang terdiri dari tiga aspek, yaitu usia, jenis kelamin, dan pendidikan, serta faktor biologis yang terdiri dari dua aspek, yaitu status gizi dan kondisi rumah (Dharmage, 2009; Notoadmojo, 2007). Syarat rumah sehat meliputi bahan bangunan yang terdiri dari jenis lantai, dinding, atap, dan tiang rumah, ventilasi, pencahayaan, serta faktor polusi yang terdiri dari dua aspek yaitu cerobong asap dan kebiasaan merokok (Suhandayani, 2007).

Faktor lain yang dapat
menyebabkan ISPA yaitu adanya pencemaran udara. Menurut Peraturan Menteri Lingkungan Hidup Nomor 12 Tahun 2010 tentang Pelaksanaan Pengendalian Pencemaran Udara di Daerah, pencemaran udara adalah masuk atau dimasukkannya zat, energi atau komponen lain ke dalam udara ambien oleh kegiatan 
manusia sehingga melampaui baku mutu udara yang telah ditetapkan. Pencemaran udara akibat kebakaran hutan, gas buang dari transportasi dan industri, asap rokok, asap pembakaran di rumah tangga, dan asap obat nyamuk bakar juga merupakan ancaman kesehatan lingkungan yang merupakan penyebab terjadinya ISPA (Depkes RI, 2009).

Substansi pencemar yang terdapat di udara dapat masuk ke dalam tubuh melalui sistem pernafasan. Jauhnya penetrasi zat pencemar ke dalam tubuh bergantung kepada jenis pencemar. Partikulat berukuran besar dapat tertahan di saluran pernapasan bagian atas, sedangkan partikulat berukuran kecil dan gas dapat mencapai paru-paru. Dari paru-paru, zat pencemar diserap oleh sistem peredaran darah dan menyebar ke seluruh tubuh (Budiman, 2006). Penyebab terjadinya ISPA dan penyakit gangguan saluran pernafasan lain adalah rendahnya kualitas udara di dalam rumah atau di luar rumah baik secara biologis, fisik, maupun kimia (Lindawaty, 2010).

Komponen rumah dan lingkungan di sekitarnya yang tidak memenuhi syarat kesehatan merupakan faktor risiko berbagai jenis penyakit, khususnya jenis penyakit yang berbasis lingkungan (Keman, 2005). Kondisi lingkungan yang buruk akan mengganggu keseimbangan interaksi antara host, agent dan environment yang biasa disebut sebagai segitiga epidemiologi. Proses tersebut berjalan dinamis dan jika salah satunya ada yang terganggu, maka akan mempengaruhi yang lainnya sehingga menyebabkan terjadinya penyakit pada host (Mubarak dan Chayatin, 2009). Kondisi lingkungan yang tidak sehat juga akan meningkatkan agent penyebab penyakit untuk berkembang biak dan akan memudahkan proses penularan penyakit (Norihwadziyah dan Keman, 2013).

Berdasarkan laporan Puskesmas Bantaran mulai tahun 2014 sampai tahun 2015, jenis penyakit yang paling banyak diderita oleh penduduk Desa Besuk adalah Infeksi Saluran Pernafasan Akut (ISPA). Jumah penderita gejala ISPA sebanyak 270 orang yang terdiri dari 91 laki-laki dan 179 perempuan. Berikut ini daftar penyakit terbanyak di Desa Besuk dari bulan Januari tahun 2014 sampai bulan Juli tahun 2015.

Tabel 1. Jenis Penyakit yang Terdapat di Desa Besuk (Puskesmas Bantaran, 2015)

\begin{tabular}{lccc}
\hline \multirow{2}{*}{ Penyakit } & \multicolumn{2}{c}{ Jumlah } & Total \\
\cline { 2 - 3 } & Laki-Laki & Perempuan & \\
\hline ISPA & 120 & 216 & 336 \\
Linu-linu & 32 & 42 & 116 \\
Diare & 25 & 56 & 81 \\
Gangguan & 26 & 33 & 59 \\
$\begin{array}{l}\text { neurotik } \\
\text { Demam }\end{array}$ & 13 & 7 & 20 \\
$\begin{array}{l}\text { Penyakit } \\
\text { otot }\end{array}$ & 44 & 89 & 133 \\
$\begin{array}{l}\text { Penyakit } \\
\text { kulit }\end{array}$ & 20 & 53 & 73 \\
$\begin{array}{l}\text { alergi } \\
\text { Darah }\end{array}$ & & & \\
tinggi \\
primer
\end{tabular}

\section{METODE PENELITIAN}

Penelitian ini menggunakan metode survei analitik dengan pendekatan cross sectional study. Tempat penelitian yaitu di Desa Besuk Kecamatan Bantaran Kabupaten Probolinggo. Populasi penelitian adalah warga Desa Besuk dengan rentang usia 20 hingga 44 tahun, serta bertempat tinggal di Dusun Krajan, Polay, Bata dan Nangka. Penentuan populasi berdasarkan laporan dari puskesmas Bantaran yaitu warga yang banyak menderita ISPA berada dalam rentang usia 20-44 tahun. Kemudian didapatkan sejumlah 1.344 orang sebagai populasi penelitian.

Pengambilan sampel dilakukan dengan menggunakan metode simple random sampling kemudian didapatkan sejumlah 60 responden sebagai sampel penelitian. Responden terdiri dari 15 responden laki-laki dan 45 responden perempuan. Responden tersebar secara acak di empat dusun di Desa Besuk. 
Tabel 2. Jumlah Responden Tiap Dusun di Desa Besuk

\begin{tabular}{lrr}
\hline \multicolumn{1}{c}{ Dusun } & Jumlah & Persentase (\%) \\
\hline Polay & 21 & 35 \\
Nangka & 18 & 30 \\
Bata & 15 & 25 \\
Krajan & 6 & 10 \\
\hline \multicolumn{1}{c}{ Total } & $\mathbf{6 0}$ & $\mathbf{1 0 0}$ \\
\hline
\end{tabular}

Pengambilan data dilakukan dengan dua cara melakukan indepth interview kepada kader, perangkat desa, bidan desa, dan pihak dari Badan Pusat Statistik (BPS) Kabupaten Probolinggo, sedangkan data kuantitaif dikumpulkan melalui survei dengan menggunakan kuesioner dan observasi langsung kepada warga Desa Besuk. Data sekunder didapatkan dari buku profil Kecamatan Bantaran tahun 2014.

Variabel independen meliputi keberadaan debu dalam ruang, frekuensi menyapu rumah, penggunaan masker saat keluar rumah, kepadatan hunian tempat tidur, luas ventilasi dapur, dan jenis lantai rumah, sedangkan variabel dependen adalah kejadian ISPA pada orang dewasa. Data penelitian diuji dengan uji statistik Chi-square dengan tingkat kemaknaan $\alpha<$ 0,1 .

\section{HASIL DAN PEMBAHASAN}

\section{Gambaran Umum Lokasi Penelitian}

Desa Besuk merupakan ibu kota Kecamatan Bantaran yang terletak pada ketinggian kurang lebih 87 meter di atas permukaan laut. Temperatur udara di Desa Besuk sama seperti daerah dataran rendah pada umumnya, yaitu suhu udaranya relatif panas. Desa Besuk memiliki luas wilayah kurang lebih 231.795 hektar yang terdiri dari 8 RT (Rukun Tetangga) dan 4 RW (Rukun Warga). Jumlah penduduk di Desa Besuk yaitu sebanyak 3.252 orang dan terdiri dari 821 kepala keluarga (KK). Jumlah penduduk terbanyak berada di Dusun Nangka yaitu sebanyak 1.066 jiwa, sedangkan penduduk dengan jumlah paling sedikit berada di Dusun Krajan yaitu sebanyak 581 jiwa (Data monografi Desa Besuk Tahun 2013).
Tabel 3. Jumlah Penduduk Tiap Dusun di Desa Besuk (Buku Profil Kecamatan Bantaran, 2014)

\begin{tabular}{cccc}
\hline Dusun & Laki-laki & Perempuan & Jumlah \\
\hline Krajan & 273 & 308 & 581 \\
Polay & 388 & 425 & 813 \\
Nangka & 502 & 564 & 1066 \\
Bata & 388 & 404 & 792 \\
\hline Total & $\mathbf{1 5 5 1}$ & $\mathbf{1 7 0 1}$ & $\mathbf{3 2 5 2}$ \\
\hline
\end{tabular}

\section{Gambaran Distribusi Kejadian ISPA}

Berdasarkan hasil pengumpulan data primer yang didapatkan dari 60 responden, distribusi kejadian ISPA terbanyak berada di Dusun Polay dengan presentase sebesar 37,5\%. Persentase terbanyak kedua adalah Dusun Nangka yaitu sebesar $31,25 \%$, disusul oleh Dusun Bata yaitu sebesar 25\%, dan Dusun Krajan sebesar 6,25\%. Berikut ini adalah distribusi kejadian ISPA berdasarkan tempat tinggal:

Tabel 4. Distribusi Kejadian ISPA

\begin{tabular}{cccc}
\hline $\begin{array}{c}\text { Dusun } \\
\text { Respon } \\
\text { den }\end{array}$ & \multicolumn{2}{c}{ Status Penyakit } & Total \\
\cline { 2 - 3 } & ISPA & Tidak ISPA & \\
\hline Krajan & 3 & 2 & 5 \\
Polay & 18 & 5 & 23 \\
Bata & 12 & 0 & 12 \\
Nangka & 15 & 5 & 20 \\
\hline Total & 48 & 12 & $\mathbf{6 0}$ \\
\hline
\end{tabular}

Dusun Polay merupakan dusun yang terletak paling dekat dengan jalan utama di Desa Besuk. Jalan tersebut menghubungkan Desa Besuk dengan desa lain sehingga Dusun Polay sering dilewati kendaraan dengan tingkat mobilitas yang tinggi. Jenis kendaraan yang melewati jalan utama beragam, mulai kendaaraan pribadi roda dua, mobil, angkutan umum, dan truk besar. Hal ini menyebabkan paparan polusi dan debu di Dusun Polay lebih tinggi dibandingkan dusun lainnya.

\section{Kejadian ISPA dan Faktor-Faktor yang Berhubungan}

Hasil uji statistik menunjukkan bahwa dari enam faktor, terdapat tiga faktor yang berhubungan dengan kejadian ISPA, yaitu keberadaan debu di dalam ruang, frekuensi menyapu rumah, dan penggunaan masker saat keluar rumah, sedangkan tiga 
faktor lain, yaitu kepadatan hunian tempat tidur, luas ventilasi dapur, dan jenis lantai rumah tidak berhubungan dengan kejadian ISPA.

Tabel 5. Analisis Bivariat Kejadian ISPA dan Faktor-Faktor yang Berhubungan

\begin{tabular}{|c|c|c|c|c|}
\hline \multirow[t]{3}{*}{ Variabel } & \multicolumn{4}{|c|}{ Status Penyakit ISPA } \\
\hline & \multicolumn{2}{|c|}{ ISPA } & \multicolumn{2}{|c|}{ Tidak ISPA } \\
\hline & $\mathbf{N}$ & $\%$ & $\mathbf{N}$ & $\%$ \\
\hline \multicolumn{5}{|l|}{ Keberadaan Debu } \\
\hline Ya & 27 & 45 & 13 & 21,67 \\
\hline Tidak & 6 & 10 & 14 & 23,33 \\
\hline & & \multicolumn{3}{|l|}{0,006} \\
\hline \multicolumn{2}{|c|}{$90 \%$ Confidence Interval } & \multicolumn{3}{|c|}{$p<\alpha=0,006<0,1$} \\
\hline \multicolumn{5}{|l|}{ Frekuensi Menyapu } \\
\hline$<2$ kali & 3 & 5 & 2 & 3,33 \\
\hline 2 kali & 22 & 36,67 & 16 & 26,67 \\
\hline$>2$ kali & 15 & 25 & 2 & 3,33 \\
\hline p value & & 0,083 & & \\
\hline $90 \%$ Confidence Inter & & $p<\alpha=$ & $=0,08$ & $<0,1$ \\
\hline \multicolumn{5}{|l|}{ Penggunaan Masker } \\
\hline Kadang-kadang & 5 & 8,34 & 0 & 0 \\
\hline Tidak pernah & 35 & 58,33 & 20 & 33,33 \\
\hline$p$ value & & 0,099 & & \\
\hline 95\% Confidence Inter & & $p<\alpha$ & $=0,0$ & $<0,1$ \\
\hline \multicolumn{5}{|l|}{ Kepadatan Kamar } \\
\hline Penghuni $>2$ orang & 18 & 30 & 10 & 16,67 \\
\hline $\begin{array}{l}\text { Penghuni }<2 \text { orang } \\
p \text { value }\end{array}$ & 22 & $\begin{array}{r}36,67 \\
0,714\end{array}$ & 10 & 16,67 \\
\hline 95\% Confidence Inter & & $p>\alpha$ & -0 & $4>0,1$ \\
\hline \multicolumn{5}{|l|}{ Luas Ventilasi Dapur } \\
\hline Tidak ada & 12 & 20 & 10 & 16,67 \\
\hline Ada,$<10 \%$ & 23 & 38,33 & 8 & 13,33 \\
\hline Ada, $>10 \%$ & 5 & 8,34 & 2 & 3,33 \\
\hline$p$ value & & 0,31 & & \\
\hline 95\% Confidence Inter & & $p>\alpha$ & $=0,3$ & $>0,1$ \\
\hline \multicolumn{5}{|l|}{ Jenis lantai } \\
\hline Tanah & 1 & 1,67 & 0 & 0 \\
\hline Plester semen & 12 & 20 & 4 & 6,67 \\
\hline Keramik/ubin & 27 & $\begin{aligned} 45 \\
0524\end{aligned}$ & 16 & 26,67 \\
\hline $\begin{array}{l}p \text { value } \\
95 \% \text { Confidence Inter }\end{array}$ & & $\begin{array}{l}0,524 \\
p>\alpha\end{array}$ & $=0,5$ & $>0,1$ \\
\hline
\end{tabular}

Tabel tersebut menunjukkan bahwa dari 60 responden, terdapat sebanyak 33 responden yang menderita ISPA ditinjau dari variabel keberadaan debu di dalam ruang dan terdapat sebanyak 40 responden yang menderita ISPA ditinjau dari variabel frekuensi menyapu rumah, penggunaan masker saat keluar rumah, kepadatan penghuni kamar, luas ventilasi dapur, serta variabel jenis lantai rumah.
Pada variabel keberadaan debu ruang, hasil dari uji statistik chi-square menunjukkan angka signifikansi atau $p$ value kurang dari $\alpha$, yaitu $0,006<0,1$ yang artinya Ho ditolak sehingga dapat disimpulkan bahwa ada hubungan antara keberadaan debu ruang dengan kejadian ISPA.

Pada variabel frekuensi menyapu rumah, hasil dari uji statistik chi-square menunjukkan angka signifikansi atau $p$ value kurang dari $\alpha(0,083<0,1)$ yang artinya Ho ditolak sehingga dapat disimpulkan bahwa ada hubungan antara frekuensi menyapu rumah dengan kejadian ISPA.

Pada variabel penggunaan masker saat keluar rumah, hasil dari uji statistik chisquare menunjukkan angka signifikansi atau $p$ value kurang dari $\alpha(0,099<0,1)$ yang artinya Ho ditolak sehingga dapat disimpulkan bahwa ada hubungan antara penggunaan masker saat keluar rumah dengan kejadian ISPA.

Pada variabel kepadatan penghuni kamar, hasil dari uji statistik chi-square menunjukkan angka signifikansi atau $p$ value lebih dari $\alpha(0,714>0,1)$ yang artinya Ho diterima sehingga dapat disimpulkan bahwa tidak ada hubungan antara kepadatan penghuni kamar dengan kejadian ISPA.

Pada variabel luas ventilasi dapur, hasil dari uji statistik chi-square menunjukkan angka signifikansi atau $p$ value lebih dari $\alpha(0,314>0,1)$ yang artinya Ho diterima sehingga dapat disimpulkan bahwa tidak ada hubungan antara luas ventilasi dapur dengan kejadian ISPA.

Pada variabel jenis lantai rumah, hasil dari uji statistik chi-square menunjukkan angka signifikansi atau $p$ value lebih dari $\alpha(0,524>0,1)$ yang artinya Ho diterima sehingga dapat disimpulkan bahwa tidak ada hubungan antara jenis lantai rumah dengan kejadian ISPA.

\section{PEMBAHASAN}

Udara merupakan kebutuhan pokok manusia untuk bernafas sepanjang hidupnya. Udara akan sangat berpengaruh dalam menentukan kenyamanan dan kesegaran, serta tercipta rumah yang sehat 
apabila terjadi pergantian udara secara kontinyu melalui berbagai ruangan dan lubang pada bidang pembatas dinding atau partisi sebagai ventilasi (Keputusan Menteri Permukiman dan Prasarana Wilayah Nomor 403 tahun 2002).

Hasil penelitian di Desa Besuk ditinjau dari variabel keberadaan debu ruang menunjukkan bahwa dari 60 responden, 33 diantaranya menderita ISPA. Hasil dari uji statistik juga menunjukkan adanya hubungan antara keberadaan debu dalam ruang dengan kejadian ISPA. Keberadaan debu dalam ruang dapat mempengaruhi kesehatan manusia karena hampir 90\% kegiatan manusia berada di dalam ruangan.

Keberadaan debu dalam ruang juga dipengaruhi oleh frekuensi menyapu rumah. Semakin jarang menyapu rumah maka debu rumah akan semakin menumpuk, akibatnya risiko terkena infeksi pada saluran pernafasan juga semakin besar. Rumah yang tidak pernah disapu akan menyebabkan akumulasi debu yang ada di dalam ruangan, jika terkena angin maka debu tersebut akan beterbangan dan terhirup oleh manusia. Debu yang terhirup akan menyebabkan saluran pernafasan terganggu dan dapat menyebabkan ISPA. Hasil dari uji statistik menunjukkan adanya hubungan antara frekuensi menyapu rumah dengan kejadian ISPA.

Hasil dari uji statistik menunjukkan adanya hubungan antara penggunaan masker saat keluar rumah dengan kejadian ISPA. Namun, saat ini belum banyak orang yang menyadari bahaya polusi udara sehingga masih sering dijumpai pengendara motor yang belum menggunakan pelindung atau masker. Padahal penggunaan masker secara teratur ketika melakukan aktivitas di luar atau kontak dengan lingkungan luar dapat mengurangi risiko terkena paparan debu secara langsung.

Sepeda motor merupakan salah satu alat transportasi yang banyak digunakan oleh masyarakat Desa Besuk untuk berbagai kebutuhan. Tidak bisa dipungkiri bahwa alat transportasi sangat berperan penting dalam kehidupan sehari-hari untuk bekerja dan berbagai kegiatan lainnya.
Kendaraan pribadi dinilai relatif lebih praktis, efisien, dan ekonomis. Namun, semakin banyak kendaraan yang berlalu lalang di jalan, maka akan semakin besar kemungkinan terjadinya polusi udara.

Hasil uji statistik menunjukkan bahwa kepadatan penghuni kamar tidak berhubungan dengan kejadian ISPA. Namun, berdasarkan teori yang ada, kepadatan penghuni kamar bisa berhubungan dengan kejadian ISPA jika salah satu penghuni merupakan penderita ISPA.

Luas rumah yang tidak sebanding dengan jumlah penghuninya akan terjadi overcrowded dan dapat menyebabkan kekurangan konsumsi $\mathrm{O}_{2}$ sehingga jika salah satu anggota keluarga terkena penyakit infeksi, maka mudah menularkan ke anggota keluarga yang lain. Kondisi kepadatan hunian sangat penting utuk diperhatikan, terutama menyangkut penularan penyakit infeksi antar individu. Gangguan pernafasan yang disebabkan oleh virus biasanya disebarkan antar penghuni dan dihantarkan memalui udara (Notoatmodjo, 2003).

Kepadatan hunian yang buruk, yaitu kurang dari $9 \mathrm{~m}^{2}$ orang akan meningkatkan frekuensi kontak, kepadatan populasi dan konsentrasi, serta kedekatan antara orang yang menjadi sumber penularan dengan orang yang rentan diantara populasi sehingga memudahkan penularan dari organisme penyebab ISPA (WHO, 2003).

Hasil uji statistik menunjukkan bahwa luas ventilasi dapur tidak berhubungan dengan kejadian ISPA. Namun, tidak demikian jika ditinjau berdasarkan teori yang ada. Pada penelitian ini, penilaian luas ventilasi dapur dibagi menjadi tiga kategori, yaitu tidak ada ventilasi, luas ventilasi $<10 \%$ dari luas lantai, dan luas ventilasi $>10 \%$ dari luas lantai. Kategori ideal yang diharapkan adalah ventilasi dapur di rumah warga Desa Besuk tergolong dalam kategori $>10 \%$ dari luas lantai. Kategori tersebut menandakan bahwa kondisi dapur telah sesuai dengan Permenkes No. 1077 tahun 2011 tentang penyehatan udara dalam ruang. 
Luas ventilasi dapur yang tidak sesuai dengan Permenkes No. 1077 tahun 2011 dapat dikategorikan kurang sehat karena laju pertukaran udara yang kurang ditambah dengan tidak adanya teknologi yang tersedia untuk menangkap asap dan zat pencemar udara lainnya di dapur. Dapur warga Desa Besuk sebagian besar masih bersifat konvensional, ventilasi dibuat seadaanya sesuai dengan kebudayaan warga dalam membuat dapur tanpa memperhatikan pentingnya keberadaan ventilasi di dapur sebagai upaya penyehatan yang telah ditetapkan oleh pemerintah.

Pertukaran udara yang tidak memenuhi syarat akan menjadi media pertumbuhan dan perkembang biakkan mikroorganisme yang dapat menimbulkan ganguan terhadap kesehatan manusia. Upaya penyehatan yang dapat dilakukan salah satunya yaitu dengan mengatur pertukaran udara. Rumah harus dilengkapi dengan ventilasi minimal $10 \%$ dari luas lantai dengan sistem ventilasi silang. Ventilasi dapur mempunyai bukaan minimal $40 \%$ dari luas lantai dengan sistem ventilasi silang sehingga terjadi aliran udara, atau bisa juga menggunakan teknologi tepat guna untuk menangkap asap dan zat pencemar udara (Permenkes No. 1077 tahun 2011).

Beberapa ketentuan agar dapat diperoleh kesegaran udara dalam ruangan, yaitu udara yang mengalir masuk harus sama dengan volume udara yang mengalir keluar ruangan, dan udara yang masuk tidak berasal dari asap dapur atau bau kamar mandi/WC (Keputusan Menteri Permukiman dan Prasarana Wilayah No. 403 tahun 2002).

Penghawaan ruangan dapur dan kamar mandi/WC memerlukan peralatan bantu elektrikal-mekanikal seperti blower atau exhaust fan yang harus memenuhi ketentuan sebagai berikut, yaitu lubang penghawaan keluar tidak mengganggu kenyamanan bangunan di sekitarnya dan tidak mengganggu kenyamanan ruangan lain seperti ruang keluarga, ruang tamu, ruang tidur, dan ruang kerja. Ventilasi yang baik akan memudahkan udara segar masuk ke dalam rumah sehingga kejadian gejala
ISPA akan semakin berkurang (Keputusan Menteri Permukiman dan Prasarana Wilayah No. 403 tahun 2002).

Berdasarkan hasil perhitungan, dari 40 responden yang menderita ISPA, 27 orang telah menggunakan lantai berbahan keramik/ubin, 12 orang menggunakan lantai berbahan plester/semen, dan hanya satu orang yang menggunakan lantai berbahan tanah. Hasil analisis statistik menunjukkan bahwa tidak ada hubungan antara jenis lantai yang digunakan dengan kejadian ISPA. Sebagian besar responden telah menggunakan keramik, namun masih terkena ISPA. Hal ini bisa saja disebabkan oleh faktor lain, salah satunya perilaku responden dalam membersihkan rumah. Walaupun jenis lantai yang digunakan sudah ideal, namun jika tidak diimbangi dengan personal hygiene, maka responden tetap bisa terjangkit penyakit ISPA.

Hasil analisis statistik tersebut sejalan dengan hasil penelitian yang dilakukan oleh Safitri dan Keman (2007) tentang hubungan tingkat kesehatan rumah dengan kejadian ISPA pada anak balita di Desa Labuan, Kecamatan Labuan Badas, Kabupaten Sumbawa yang membuktikan bahwa tidak ada hubungan antara jenis lantai rumah dengan kejadian ISPA. Penelitian tersebut juga sejalan dengan penelitian yang dilakukan oleh Soolani, dkk. (2015), namun tidak sejalan dengan penelitian yang dilakukan oleh Yuwono (2008) bahwa jenis lantai mempunyai hubungan yang bermakna dengan kejadian pneumonia. Hal tersebut juga diperkuat dengan penelitian yang dilakukan oleh Padmonobo, dkk. (2012).

Menurut Kepmenkes No. 829 tahun 1999 tentang persyaratan kesehatan rumah tinggal, lantai rumah yang ideal terbuat dari ubin, keramik, atau semen. Tinggi lantai dasar suatu bangunan diperkenankan mencapai maksimal 1,2 $\mathrm{m}$ di atas tinggi rata-rata tanah pekarangan atau tinggi ratarata jalan dengan memperhatikan keserasian lingkungan. Tinggi minimum lantai menurut Peraturan Menteri PU No. 29 tahun 2006 adalah $15 \mathrm{~cm}$ dari pekarangan rumah dan $25 \mathrm{~cm}$ dari badan jalan. Lantai yang terbuat dari tanah tidak 
bersifat kedap air, berdebu dan sulit dibersihkan. Debu yang terhirup setiap hari dapat mengganggu saluran pernafasan. Hal tersebut merupakan salah satu faktor risiko terjadinya ISPA.

\section{SIMPULAN DAN SARAN}

Warga Desa Besuk yang berisiko besar terkena ISPA berada dalam rentang usia 20-44 tahun. Distribusi kejadian ISPA terbanyak berada di Dusun Polay dengan presentase sebesar $37,5 \%$. Persentase terbanyak kedua adalah Dusun Nangka yaitu sebesar 31,25\%, disusul oleh Dusun Bata yaitu sebesar 25\%, dan Dusun Krajan sebesar $6,25 \%$.

Hasil uji statistik menunjukkan bahwa dari enam faktor, terdapat tiga faktor yang berhubungan dengan kejadian ISPA, yaitu keberadaan debu di dalam ruang, frekuensi menyapu rumah, dan penggunaan masker saat keluar rumah, sedangkan tiga faktor lain, yaitu kepadatan hunian tempat tidur, luas ventilasi dapur, dan jenis lantai rumah tidak berhubungan dengan kejadian ISPA. Hal ini menunjukkan bahwa warga Desa Besuk belum maksimal dalam menjaga kebersihan rumah dan menjaga diri dari polutan berbahaya di lingkungan.

Warga Desa Besuk hendaknya selalu menjaga kebersihan lingkungan di sekitarnya, terutama lingkungan rumah, serta selalu menjaga kesehatan diri sendiri dengan berperilaku hidup bersih dan sehat. Warga Desa Besuk juga disarankan untuk memakai alat pelindung diri berupa masker saat bepergian ke luar rumah. Sebab, kondisi lingkungan di Desa Besuk berdebu, apalagi saat musim kemarau.

Perangkat Desa Besuk diharapkan dapat bekerja sama dengan bidan dan kader posyandu untuk memberikan penyuluhan yang berkaitan dengan ISPA kepada seluruh warga Desa Besuk, baik melalui diskusi ataupun yang lainnya. Perangkat Desa Besuk diharapkan senantiasa mendukung dan ikut berperan aktif dalam program yang diadakan oleh bidan dan kader posyandu.

Saran yang dapat diberikan kepada pihak Puskesmas Kecamatan Bantaran yaitu Puskesmas Bantaran diharapkan dapat bekerjasama dengan berbagai pihak untuk membantu menyelesaikan masalah kesehatan yang terjadi di setiap desa di kecamatan Bantaran. Selain itu, Puskesmas Bantaran hendaknya dapat memberdayakan klinik sanitasi untuk fokus dalam kesehatan lingkungan, khususnya lingkungan rumah yang terkait dengan upaya penanggulangan ISPA.

\section{DAFTAR PUSTAKA}

Badan Perencanaan Pembangunan Daerah Kabupaten Probolinggo dan BPS Kabupaten Probolinggo. 2014. Profil Kecamatan Bantaran. BPPD dan BPS Probolinggo. Probolinggo

Budiman, C. 2006. Pengantar Kesehatan Lingkungan. Jakarta: EGC

Departemen Kesehatan Republik Indonesia. 2009. Profil Kesehatan Indonesia 2008. Depkes RI. Jakarta

Dharmage, D. 2009. Risk Factor of Acute Lower Tract Infection in Children Under Five Years of Age. Medical Public Health

Halim, F. 2012. Hubungan Faktor Lingkungan Fisik dengan Kejadian ISPA pada Pekerja di Industri Mebel Dukuh Tukrejo, Desa Bondo, Kecamatan Bangsri, Kabupaten Jepar, Propinsi Jawa Tengah 2012. Skripsi. Jakarta: Universitas Indonesia

Keman, S. 2005. Kesehatan Perumahan dan Lingkungan Perumahan, Jurnal Kesehatan Lingkungan, Volume 2 No. 1

Keputusan Menteri Kesehatan Republik Indonesia Nomor 829 Tahun 1999 Persyaratan Kesehatan Rumah Tangga. Lembaran Negara Republik Indonesia. Jakarta

Keputusan Menteri Permukiman dan Prasarana Wilayah Nomor 403 Tahun 2002 Pedoman Teknsis Pembangunan Rumah Sederhana Sehat. Lembaran Negara Republik Indonesia. Jakarta

Lindawaty, L. 2010. Partikulat $\left(\mathrm{PM}_{10}\right)$ Udara Rumah Tinggal yang Mempengaruhi Kejadian ISPA pada Balita di Kecamatan Mampang. Skripsi. Jakarta: Universitas Indonesia 
Mubarak, W. dan Chayatin, N. 2009. Ilmu Kesehatan Masyarakat: Teori dan Aplikasi. Jakarta: Rineka Cipta

Norihwadziyah, I. V. dan Keman, S. 2013. Hubungan Kesehatan Rumah dengan Kejadian ISPA pada Anak Balita di Wilayah Kerja Puskesmas Baamang I Kecamatan Baamang Kabupaten Kotawaringin Timur. Jurnal Kesehatan Lingkungan Vol. 7, No. 1 Juli 2013: 171-178

Notoatmodjo, S. 2003. Ilmu Kesehatan Masyarakat. Jakarta: Rineka Cipta.

Notoatmodjo, S. 2007. Promosi Kesehatan dan Ilmu Perilaku. Jakarta: Rineka Cipta.

Padmonobo, H. Onny, S. dan Tri, J. 2012. Hubungan Faktor-Faktor Lingkungan Fisik Rumah dengan Kejadian Pneumonia pada Balita di Wilayah Kerja Puskesmas Jatibarang Kabupaten Brebes. Jurnal Kesehatan Lingkungan Indonesia Vol. 11 No. 2

Peraturan Menteri Pekerjaan Umum Nomor 29 Tahun 2006 Pedoman Persyaratan Teknis Bangunan Gedung. 1 Desember 2006. Lembaran Negara Republik Indonesia. Jakarta

Peraturan Menteri Kesehatan Nomor 1077 Tahun 2011 Upaya Penyehatan Udara dalam Ruang. 27 Mei 2011. Lembaran Negara Republik Indonesia. Jakarta

Riduwan, A. 2014. Penulisan Sumber Kutipan dan Daftar Pustaka (Tugas akhir, Skripsi, Tesis, Disertasi, dan artikel Jurnal): Harvard-American Psychological Association Style. Surabaya: STIESIA

Safitri, A. D. dan Keman, S. 2007. Hubungan Tingkat Kesehatan Rumah dengan Kejadian ISPA pada Anak Balita di Desa Labuan Kecamatan Labuan Badas Kabupaten Sumbawa. Jurnal Kesehatan Lingkungan Vol. 3 No. 2: 139-150

Soolani, Centiany, D. Umboh, J. M. L. Dan Akili, R. H. 2015. Hubungan antara Faktor Lingkungan Fisik Rumah dengan Kejadian Infeksi Saluran Pernafasan (ISPA) pada Balita di Kelurahan Malalayang 1 Kota Manado. Dilihat 22 September 2015
$<$ http://fkm.unsrat.ac.id/wpcontent/ uploads/2015/02/JURNAL-Deflyn

Soolani-101511003.pdf $>$

Suhandayani, I. 2007. Faktor-Faktor yang Berhubungan dengan Kejadian ISPA pada Balita di Puskesmas Pati I Kabupaten Pati Tahun 2006. Dilihat $12 \quad$ Agustus 2015 $<\underline{\text { http://digilib.unimus.ac.id/download. }}$ php?id=7649.pdf $>$

WHO. 2003. Penanganan ISPA pada Anak di Rumah Sakit Kecil Negara Berkembang. Jakarta: Penerbit Buku Kedokteran EGC

WHO. 2007. Infection Prevention and Control of Epidemic and Pandemic Prone Acute Respiratory Diseases in Health Care. WHO. Jenewa. Terjemahan Trust Indonesia. 2007. Pencegahan dan Pengendalian Infeksi Saluran Pernafasan Akut (ISPA) yang Cenderung Menjadi Epidemi dan Pandemi di Fasilitas Pelayanan Kesehatan. Trust Indonesia.

WHO. 2016. Respiratory Tract Disease. Dilihat $15 \quad$ Juli 2016. $<$ http://www.who.int/topics/respirator $y$ tract diseases/en/>

Yuwono, T. A. 2008. Hubungan antara Faktor-Faktor Lingkungan Fisik Rumah dengan Kejadian Pneumonia pada Anak Balita di Wilayah Kerja Puskesmas Kawunganten Kabupaten Cilacap. Dilihat 1 Desember 2015 $<$ http://www.journal -kesehatanispa.html> 
JURNAL ILMIAH KESEHATAN MEDIAHUSADA ｜ VOLUME 06/NOMOR 01/MARET 2017 